\title{
A COMPARISON OF OLFACTORY STIMULATION AND NUTRITIONAL STRESS AS PREGNANCY-BLOCKING AGENTS IN MICE
}

\author{
H. M. BRUGE* \\ Division of Experimental Biology, \\ National Institute for Medical Research, Mill Hill, London, N.W.7
}

(Received 31st January 1963)

\begin{abstract}
Summary. Evidence is presented that olfactory stimulation and nutritional stress are separate and distinct pregnancy-blocking agents, and that the latter is not a complicating factor in the reaction set up by the former.
\end{abstract}

\section{INTRODUCTION}

In the laboratory mouse implantation can be prevented either by olfactory stimuli from male mice (Bruce, 1959, 1960) or by short periods of nutritional stress (McClure, 1958, 1959). Exposure of the female to either of these hazards leads to depression of hypophyseal function. Olfaction was not implicated in the effects ascribed by McClure to the nutritional stress imposed by $48 \mathrm{hr}$ of fast. This is clear from the conditions under which the experiments were conducted, but the elimination of nutritional stress in the experiments described by Bruce was less certain. Evidence in favour of olfaction as the primary stimulus causing pregnancy block in the latter experiments has been published elsewhere (Bruce \& Parrott, 1960; Parkes \& Bruce, 1962), but the possibility remained that exposure to males induced a reaction sufficiently intense in some recentlymated females to produce anorexia, the resulting self-imposed nutritional stress then augmenting the effects produced by olfactory stimulation from males.

The idea that exposure to males might constitute a social stress for the recentlymated female is rendered plausible from the behaviour of laboratory mice in experimental colonies, for it has been noticed that pregnant females tend to congregate together and to drive away other mice ( $\mathrm{J}$. Godfrey, personal communication). Similar behaviour has been observed by Crowcroft (1962) in studies with wild mice; indeed, he states that "one pregnant female set up her own territory, from which she drove all other mice, even the males, and successfully reared her litter". Nevertheless, according to the published accounts certain differences, particularly in the time-relations of the response, appear to exist between the McClure effect and pregnancy-block of olfactory origin. With the object of differentiating clearly between the effect of olfactory stimulation and that of short periods of nutritional stress a direct comparison was made in simultaneous tests.

* Present address: Department of Experimental Medicine, Tennis Court Road, Cambridge. 


\section{MATERIALS AND METHODS}

The female mice were $\mathrm{P}$ strain albino from the randomly-bred closed colony maintained in this Institute. The stud males belonged either to the $\mathbf{P}$ strain or to the TO strain (Gledhill, 1959). Both strains have been used extensively in pregnancy-block experiments.

The mice were housed in metal boxes $12 \times 6 \times 4$ in. with a food basket and a water bottle inserted through the lid at one end. Sawdust was used as floor covering; nesting material was provided only towards the end of gestation for the females which remained pregnant. Cubed Diet 4IB was given throughout. It has the following composition:

Wheatmeal

Sussex ground oats

White fish meal

Dried skimmed milk

Dried yeast

Sodium chloride
Composition (\%)

47

40

8

3

1

100

To each ton of diet is added $2 \frac{1}{2} \mathrm{lb}$ of stabilized vitamin supplement which supplies:

$\begin{array}{ll}\text { Vitamin A } & 4,000,000 \text { units } \\ \text { Vitamin D3 } & 1,000,000 \text { units } \\ \text { Vitamin B2 } & 1.5 \mathrm{~g} \\ \text { Vitamin B12 } & 0.00325 \mathrm{~g} \\ \text { Vitamin B1 } & 0.5 \mathrm{~g} \\ \text { Pantothenic acid } & 0.5 \mathrm{~g} \\ \text { Nicotinic acid } & 2.5 \mathrm{~g} \\ \text { Vitamin E } & 1.25 \mathrm{~g} \\ \text { Vitamin K } & 0.5 \mathrm{~g} \\ \text { Choline chloride } & 25.0 \mathrm{~g}\end{array}$

and 2 to $3 \%$ of molasses to bind the cubes. No supplements were given. Drinking water was always available. The temperature of the room was maintained at about $20^{\circ} \mathrm{C}$.

The procedure developed to test the olfactory block to pregnancy was used. Young females 2 to 3 months of age were paired with stud males and examined daily for mating. When a vaginal plug was found (Day 0 of the experiment), the female was separated from the stud male and housed alone or in groups of five to eight females per box, as indicated in the Tables, for $24 \mathrm{hr}$.

The females, still in the same group, were then subjected to one of three conditions:

(a) For 'olfactory stimulation' they were transferred to a box containing males alien to the stud male (i.e. belonging to a different strain from him). 
(b) For 'nutritional stress' they were put in a clean box containing no food but to which a pot of water was added in addition to the usual bottle of drinking water.

(c) Controls were moved to a clean box containing the usual ration of food and water.

They remained in the test situation for 1, 2 or 3 days as indicated in the text.

At the end of the test period the females were returned to the box they had originally occupied after separation from the stud males. Females which had

TABLE 1

MAXIMUM EFFECT

\begin{tabular}{|c|c|c|c|c|c|c|}
\hline Treatment & $\begin{array}{c}\text { Duration } \\
\text { (vaginal plug } \\
\text { Day 0) }\end{array}$ & Housed & $\begin{array}{c}\text { No. } \\
\text { mated } \\
\text { females }\end{array}$ & $\begin{array}{c}\text { Females } \\
\text { remaining } \\
\text { pregnant }\end{array}$ & $\begin{array}{c}\text { Females } \\
\text { returning } \\
\text { to } \\
\text { oestrus }\end{array}$ & $\begin{array}{c}\text { Proportion } \\
\text { blocked } \\
\text { pregnancies } \\
(\%)\end{array}$ \\
\hline $\begin{array}{l}\text { Olfactory stimulation } \\
(72 \mathrm{hr})\end{array}$ & Days $1+2+3$ & Singly & 24 & 9 & 15 & $63^{*}$ \\
\hline Fasted $(48 \mathrm{hr})$ & $\begin{array}{l}\text { Days } 1+2 \\
\text { Days } 3+4\end{array}$ & $\begin{array}{l}\text { Singly } \\
\text { Grouped } \\
\text { Singly } \\
\text { Grouped }\end{array}$ & $\begin{array}{r}22 \\
45 \\
7 \\
7\end{array}$ & $\begin{array}{l}- \\
6 \\
- \\
-\end{array}$ & $\begin{array}{r}22 \\
39 \\
7 \\
7\end{array}$ & $92 *$ \\
\hline Control & & Singly & 36 & 32 & 4 & 11 \\
\hline
\end{tabular}

* Difference highly significant, $0.01>P>0.001$.

fasted received, for the first $24 \mathrm{hr}$, in addition to the food cubes, a pot of diet moistened to a soft paste.

Daily vaginal smears were examined throughout.

\section{RESULTS}

\section{MAXIMUM PREGNANCY BLOCK}

Olfactory stimulation during Days 1, 2 and 3 gave $63 \%$ blocked pregnancies, while a fast of $48 \mathrm{hr}$, in the absence of males, resulted in $92 \%$ blocked pregnancies (Table 1). Of thirty-six control females only four failed to maintain pregnancy: hence, only $11 \%$ of the females in the experimental groups would be expected to fail in the absence of special interference.

The six females which remained pregnant notwithstanding a $48 \mathrm{hr}$ fast gave birth to litters of normal size (four to nine young per litter) and a total of forty-four young were born, of which only one was stillborn. Nevertheless, five of the six females bore litters 12 to $24 \mathrm{hr}$ later than expected. All these females came from among those housed in groups.

TIME OF STIMULATION

Olfactory stimulation for only $24 \mathrm{hr}$ on Day 1 was sufficient to cause the block to pregnancy in $46 \%$ of females (Table 2). On Day 3, however, an exposure of 
this duration was virtually without effect, although as has been previously demonstrated, exposure for 3 days, beginning on Day 3, still prevents pregnancy in a high proportion of females (Bruce, 1961).

In striking contrast, $24 \mathrm{hr}$ fasting on Day 1 was only about half as effective as when the fast took place on Day $3(28 \%$ and $54 \%$ of blocked pregnancies,

TABLE 2

RESPONSES TO THE SAME TIME SCHEDULES

\begin{tabular}{|c|c|c|c|c|c|c|c|}
\hline Treatment & $\begin{array}{c}\text { Vaginal } \\
\text { plug } \\
=\text { Day } 0\end{array}$ & Housed & $\begin{array}{c}\text { No. } \\
\text { mated } \\
\text { females }\end{array}$ & $\begin{array}{c}\text { Females } \\
\text { remaining } \\
\text { pregnant }\end{array}$ & $\begin{array}{c}\text { Females } \\
\text { returning } \\
\text { to } \\
\text { oestrus }\end{array}$ & $\begin{array}{c}\text { Proportion } \\
\text { of blocked } \\
\text { pregnancies } \\
(\%)\end{array}$ & $\begin{array}{c}\text { Significance } \\
\text { of } \\
\text { difference } \\
\text { from controls }\end{array}$ \\
\hline $\begin{array}{l}\text { Olfactory stimulation } \\
(24 \mathrm{hr})\end{array}$ & $\begin{array}{l}\text { Day } 1 \\
\text { Day } 3\end{array}$ & $\begin{array}{l}\text { Singly } \\
\text { Singly }\end{array}$ & $\begin{array}{l}48 \\
44\end{array}$ & $\begin{array}{l}24 \\
36\end{array}$ & $\begin{array}{r}22 \\
5\end{array}$ & $\begin{array}{l}46 \\
11\end{array}$ & $P<0.001$ \\
\hline \multirow[t]{2}{*}{ Fasted (24 hr) } & & $\begin{array}{l}\text { Singly } \\
\text { Grouped }\end{array}$ & $\begin{array}{l}36 \\
24\end{array}$ & $\begin{array}{l}23 \\
18\end{array}$ & $\begin{array}{r}12 \\
5\end{array}$ & \} 28 & $0.05>P>0.02$ \\
\hline & Day 3 & Singly & 24 & 11 & 13 & 54 & \\
\hline Control & & Singly & 35 & 31 & 2 & 6 & \\
\hline
\end{tabular}

respectively). Litter size was again unaffected by the fasting; and in these females there was no prolongation of pregnancy.

\section{LATENT INTERVAL BEFORE THE RETURN OF OESTRUS}

When pregnancy is blocked by olfactory stimulation the latent interval in about $90 \%$ of females, before the reappearance of vaginal cornification, is 3 to 4 days after the introduction of the male, irrespective of the duration of exposure. Extension of the period of exposure affects the proportion of females which respond but not the rate of response (Bruce, 1961). After exposure to males beginning on Day 1 the females in which pregnancy was blocked show vaginal cornification on Days 3 and 4 post coitum whether the duration of exposure was for 1 or 3 days; similarly, for exposures which began on Day 3, vaginal cornification reappeared on Day 6 post coitum whether the exposure had been for 1 or 3 days (Table 3 ).

This virtually constant time schedule was not found with females in which pregnancy had failed as a result of nutritional stress. Recently-mated females fasted for $24 \mathrm{hr}$ on Day 1 did not show vaginal cornification until Days 4 and 5, i.e. $24 \mathrm{hr}$ later than females in which pregnancy had been blocked by olfactory stimuli. If a fast started on Day 1 was maintained for $48 \mathrm{hr}$, the return of oestrus was also delayed by this interval so that vaginal cornification was not observed until Days 5 and 6 post coitum. When the period of fast did not start until Day 3 the same effect was seen. After nutritional stress, therefore, oestrus recurs 3 to 4 days after the end of fasting, so that the return of vaginal cornification is not related to the withdrawal of food, i.e. to the start of the period of stress, but to its termination. 
CHANGES IN BODY WEIGHT AND APPETITE

There is a dramatic loss of body weight in fasted mice, considerably in excess of that which can be attributed to loss of gut contents (McClure, 1962). In the present experiments females exposed to males did not lose weight (Text-fig. 1),

TABLE 3

LATENT INTERVAL BEFORE THE RETURN OF OESTRUS

\begin{tabular}{|c|c|c|c|c|c|c|c|c|c|c|}
\hline \multirow{2}{*}{$\begin{array}{c}\text { Treatment started } \\
\text { (vaginal plug }=\text { Day } 0)\end{array}$} & \multirow{2}{*}{ Duration $(h r)$} & \multirow{2}{*}{$\underset{\substack{\text { No. } \\
\text { blocked } \\
\text { pregnancies }}}{ }$} & \multicolumn{8}{|c|}{$\begin{array}{l}\text { Females returning to oestrus } \\
\text { (days after coitus) }\end{array}$} \\
\hline & & & 3 & 4 & 5 & 6 & 7 & 8 & 9 & 10 \\
\hline $\begin{array}{l}\text { Olfactory stimulation } \\
\text { Day } 1\end{array}$ & $\begin{array}{l}24 \\
72\end{array}$ & $\begin{array}{l}22 \\
15\end{array}$ & $\begin{array}{r}11 \\
9\end{array}$ & $\begin{array}{r}10 \\
6\end{array}$ & 1 & & & & & \\
\hline Day 3 & $\begin{array}{l}24 \\
(72) *\end{array}$ & $\begin{array}{c}5 \\
(20)\end{array}$ & & & & $\begin{array}{c}4 \\
(19)\end{array}$ & (1) & & 1 & \\
\hline $\begin{array}{l}\text { Nutritional stress } \\
\text { Day } 1\end{array}$ & $\begin{array}{l}24 \\
48\end{array}$ & $\begin{array}{l}17 \\
61\end{array}$ & & 7 & $\begin{array}{r}8 \\
20\end{array}$ & $\begin{array}{r}1 \\
40\end{array}$ & $\begin{array}{l}1 \\
1\end{array}$ & & & \\
\hline Day 3 & $\begin{array}{l}24 \\
48\end{array}$ & $\begin{array}{l}13 \\
14\end{array}$ & & & & 5 & $\begin{array}{l}7 \\
7\end{array}$ & $\begin{array}{l}1 \\
5\end{array}$ & 1 & 1 \\
\hline
\end{tabular}

* Previously recorded (Bruce, 1961).

nor, if body weight can be regarded as a rough index of food intake, was appetite impaired in this situation. Indeed, recovery of appetite after the normal

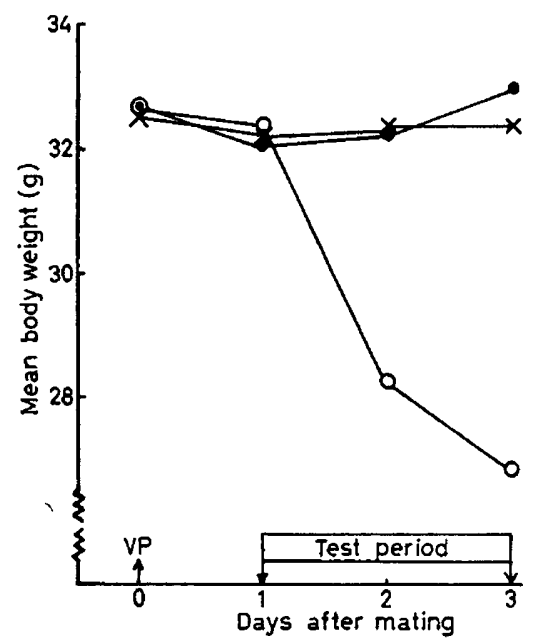

Text-FIG. 1. Mean change in body weight during the first 3 days of pregnancy. $O$, Fasting (twenty-four females) $\times$, Control (twenty-eight females). 0 ,Olfactory stimulation (twentyfour females). vP, Vaginal plug found.

decrease at oestrus may be even more rapid after mating among females housed with males than among females housed alone. This was reflected in the 
distribution of individual weight changes during test for these two groups (Text-fig. 2) and also in a highly significant difference $(P \leqslant 0 \cdot 001)$ in the mean change of body weight during test; the weight of the control females was un-
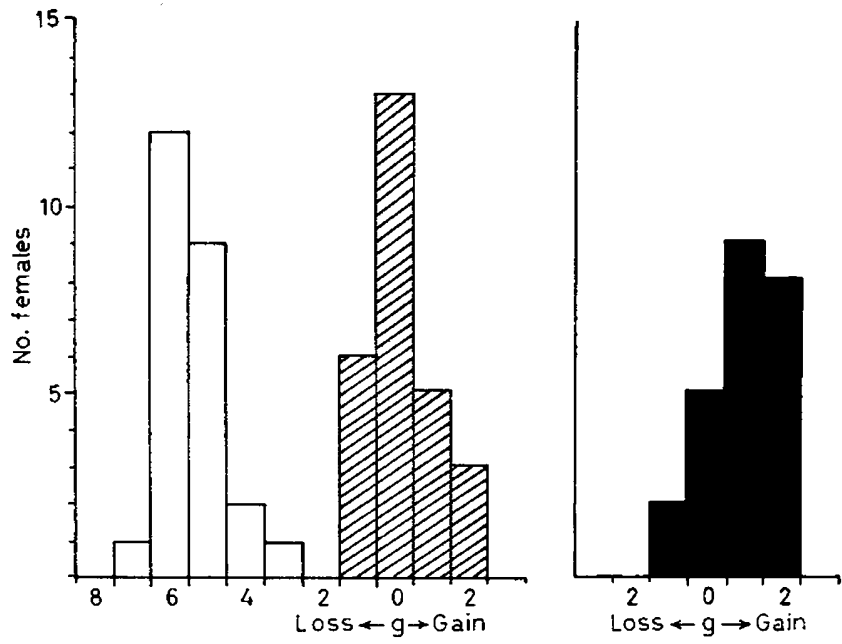

Text-Fig. 2. Distribution of individual body weight changes during test. $\square$, Fasting

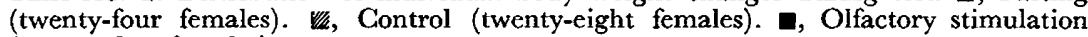
(twenty-four females).

changed while those receiving olfactory stimulation gained a mean of $0.96 \mathrm{~g}$. The mean loss of body weight during the test period for the fasted females was $5 \cdot 5 \mathrm{~g}$.

\section{DISCUSSION}

Little doubt remains, after consideration of these results, that two distinct reactions are concerned, and that they differ fundamentally in chronology and possibly in certain physiological effects also. Nutritional stress is therefore not involved in the olfactory block to implantation.

Olfactory stimulation from males is slower to take effect than fasting, since 3 days of continuous exposure is necessary to produce a maximum number of blocked pregnancies compared with 2 days of fast. Moreover, maximum sensitivity to the two effects occurs at different times.

The only direct effect of olfactory stimulation seems to be to inhibit pituitary luteotrophic activity. After fasting not only is luteotrophic activity depressed but oestrogenic activity is also affected since the return of vaginal cornification occurs only when food is restored.

In both tests the grouped females seemed better able to withstand fasting than single ones. Social effects on the oestrous cycle are well known. When females are housed in small groups there is an increase in the number of spontaneous pseudopregnancies, while these are few among mice housed singly. The presence of other females increases luteotrophic activity by the pituitary (Lee \& Boot, 1956). This effect, if it operates in the mated as well as in unmated females, may explain the slight advantage shown by grouped females in resistance to nutritional stress. 
The short delay in parturition which may represent a delay in implantation in females which remained pregnant in spite of $48 \mathrm{hr}$ of fast, suggests that at this stage of pregnancy the exact time at which fasting ends may be highly critical for the life of the blastocyst.

A fast of only $24 \mathrm{hr}$ was enough to prevent implantation in nearly half the females so treated. This result was unexpected and may be significant, because the mice used by McClure (1959) were able to withstand such a fast without any effect on fertility. While strain differences probably exist in the ability to withstand fasting it seems more likely that the discrepancy between the results can be explained by differences in the composition of the diets used. On this assumption Diet $41 \mathrm{~B}$ must be regarded as nutritionally less adequate than the standard pellet diet received by McClure's mice, since the latter endowed them with a greater resistance to nutritional stress. The nature of the dietary deficiency which so promptly affects the normal functioning of the pituitary is not yet established. According to McClure (1959) carbohydrate appears to be the critical factor.

\section{ACKNOWLEDGMENTS}

It is a pleasure to thank Miss M. V. Mussett for the tests of statistical significance and Professor A. S. Parkes, G.B.E., F.R.s. for continued interest in the work and for much helpful criticism.

\section{REFERENCES}

BRuce, H. M. (1959) An exteroceptive block to pregnancy in the mouse. Nature, Lond. 184, 105.

BRUCE, H. M. (1960) A block to pregnancy in the mouse caused by proximity of strange males. $\mathcal{F}$. Reprod. Fertil. 1, 96.

Bruce, H. M. (1961) Time relations in the pregnancy-block induced in mice by strange males. $\mathcal{F}$. Reprod. Fertil. 2, 138.

Bruce, H. M. \& PARrott, D. M. V. (1960) Role of olfactory sense in pregnancy block by strange males. Science, 131, 1526.

GROWCROFT, W. P. (1962) Relating the laboratory environment to nature. Laboratory Animals Collected Papers, 11, 9.

GLEDHILl, A. W. (1959) The effect of bacterial endotoxin on resistance of mice to ectromelia. Brit. $\mathcal{F}$. exp. Path. 40, 195.

MaCiure, T. J. (1958) Temporary nutritional stress and infertility in mice. Nature, Lond. 181, 1132.

MCGlure, T. J. (1959) Temporary nutritional stress and infertility in female mice. F. Physiol. 147, 221.

McClure, T. J. (1962) Infertility in female rodents caused by temporary inanition at or about the time of implantation. F. Reprod. Fertil. 4, 241.

Parkes, A. S. \& Bruce, H. M. (1962) Pregnancy-block in female mice placed in boxes soiled by males. 7. Reprod. Fertil. 4, 303.

VAN DER LEE, S. \& Boot, L. M. (1955) Spontaneous pseudopregnancy in mice. Acta physiol. pharm. néerl. 4. 442. 